\title{
Is There a Role for the BRICS in Asian Affairs?
}

\author{
H. Niu
}

Haibin Niu - PhD, deputy director, Center for American Studies, assistant director, Institute for International Strategy Studies, Shanghai Institutes for International Studies; 195-15 Tianlin Road, Shanghai 200133, China; E-mail: niuhaibin@siis.org.cn

The BRICS group of Brazil, Russia, India, China and South Africa is an important rising force in the current global governance system. From 2009 the priorities for cooperation among the BRICS countries were on reforming major international financial institutions; in recent years these have been extended to include international security and development issues. At the regional level, BRICS leaders held dialogues with their counterparts in Africa and South America during the two latest BRICS summits. However, the BRICS group has not paid much attention to Asian economic issues or security issues in East Asia. The weak and unbalanced agenda of the BRICS toward Asian affairs is unusual considering the fact that the BRICS includes three prominent Asian members with global ambitions, and the overall importance of Asia to BRICS members. The absence of a strong Asian agenda within the BRICS reflects some of the dimensions of the group and the region itself. First of all, the priority of the BRICS countries is to promote their global status, which makes global issues more attractive for them than regional issues. Second, Asian members of the BRICS are not capable of solving Asian security challenges individually or collectively. Third, unlike Africa and South America, Asia is not a highly integrated region - partially due to competition among major powers including the Asian members of the BRICS. However, considering the region's rising importance and challenges, the BRICS cannot avoid exploring its influence in shaping Asia's future. In order to improve their influence in the region against the background of competing regional institutions and the renewed interest of the United States in Asia, BRICS countries need to coordinate their individual approaches to Asia, provide more regional public goods by multilateral means, offer either solutions or ideas for regional security issues and find a more sustainable way to engage with the region.

Key words: BRICS, global governance, Asia, New Development Bank

\section{Introduction}

The BRICS grouping of Brazil, Russia, India, China and South Africa was originally known as "BRIC" before South Africa joined in 2011. The BRIC was an investment concept created by Jim O'Neill in 2001 to refer to Brazil, Russia, India and China as major emerging economies [O'Neill, 2001]. From then on, the term was widely used to indicate the shift of international economic power from the advanced economies to the developing economies. Following this logic of treating the BRIC countries as emerging economies, the international community tends to view the role of the BRICS in global governance from an economic perspective. For example, by establishing the Group of Eight Plus Five (G8+5) process, the G8 members explored the potential for economic cooperation on sustainable development issues with five major developing countries, namely China, India, Brazil, Mexico and South Africa. The main objective for upgrading the G20 ministerial meetings to G20 leaders' summits in 2008 was to deal with the global financial crisis by mobilizing the resources of all the major economies, especially the BRICS countries. 
While it is important to assess the impact of the cooperation among BRICS countries from an economic perspective, non-economic factors also have an important impact on the participation of these major emerging economies in global governance. The institutionalization of the G8 +5 dialogue process by initiated Germany eventually ended due to lack of support from the G8 after Japan hosted the 2008 summit, even though Italy tried to renew it in 2009. Since the major developing countries all felt unequally treated by the G8 members during the G $8+5$ dialogue process, the process unexpectedly cultivated cooperative habits and generated the intention of building an equal partnership among the BRICS members. Against the backdrop of the 2008 global financial crisis, the first scheduled BRIC summit was held in 2009, which signified the beginning of the BRICs countries use of their collective economic power to participate in the global economic governance system. South Africa was invited by China to join the summit in 2011, which made the group's geographic coverage more globally representative.

Even though the BRICS was involved in global economic governance at the group's initial stage, before its creation most of the BRICS members were well known as regional players rather than as global ones. China's international role began to be visible through its leadership in helping countries in the region to deal with the 1997-1999 Asian financial crisis. South Africa's membership in the BRICS was mainly based on its regional influence rather than its global status as an emerging economy. It is easily understand why the BRICS leaders invited other African and South American leaders to dialogue with them at the recent BRICS summits in South Africa and Brazil respectively. Such initiatives to hold dialogues between BRICS leaders and their regional counterparts reflected the intention of the summit host to build a stronger image of regional leadership by highlighting its BRICS membership. However, it was noteworthy that none of the three Asian members did so when they chaired the summits. Given the importance of Asia in today's international system, it is worth exploring why the BRICS lacks a strong regional agenda for engaging with Asia. It is also meaningful to analyze the potential role of the BRICS in dealing with Asian affairs.

\section{Asian Factors in the BRICS}

One prominent feature of the BRICS group is that three members - China, India and Russia are from Asia, which reflects the region's dynamic in the current international system. Russia and China are both permanent members of the United Nations Security Council (UNSC), and India is one of the most competitive candidates for a permanent seat. China's and India's international roles as rising powers have been widely discussed by international relations scholars in recent decades. The BRICS is thus a useful tool for examining the intentions and policy choices of these rising powers in dealing with regional and global issues. One interesting aspect of the BRICS is that it focuses mainly on international economic governance and the reform of the decision-making structure of the established international financial institutions, including the International Monetary Fund (IMF) and the World Bank, by contributing to the response to the 2008 global financial crisis. Asian economic affairs have not been on the agenda of the BRICS summits because the 2008 financial crisis was mainly centred in developed countries.

Nonetheless, the declarations of the six BRIC(S) summits before 2014 demonstrated some collective concern with Asian security. Since scholars typically focus on East Asia when talking about Asia, it is necessary to clarify that Asia here refers generally to East Asia, West Asia, Central Asia and South Asia. One interesting finding is that most of the Asian issues addressed by the BRICS relate to security issues in the "broader Middle East," namely West Asia and Central Asia. Since the third BRICS summit hosted by India in 2012, the BRICS countries have expressed their security-related concerns to include Iran's nuclear project, the post-war 
construction of Iraq and Afghanistan, and the situation in Syria. Since the first summit hosted by Russia in 2009, terrorism has consistently caught the attention of the BRICS summits. The BRICS leaders at their summit in 2010 criticized terror attacks in Russia and India. When they gathered in China, the leaders showed their support for collaboration to provide relief for disasters such as the 2011 earthquake in Japan, which demonstrates that BRICS summits address both traditional and non-traditional security issues.

India, Brazil and South Africa are trying to play a larger role in the UNSC. Their views on global security challenges, including those in Asia, thus provide important input for the rest of the world in deciding whether to support their bids for permanent seats. Under the administration of Luiz Inácio Lula da Silva, Brazil's influence was extended to Africa and the Middle East, as demonstrated by the increasing numbers of its diplomatic institutions and joint efforts with Turkey to solve the Iran nuclear crisis in 2010. The perspective of Asian powers including China, India and Russia emerges partially when BRICS leaders talk about global issues, not necessarily Asian affairs. Generally speaking, the BRICS has strong Asian power membership but a weak agenda on Asian affairs so far.

\section{Why Is the BRICS Asian Agenda Weak?}

First of all, raising their global status is clearly a priority for all the BRICS countries, but they lack a prominent global forum to support this objective, which makes them more interested in dealing with global issues rather than regional ones. As a forum for rising powers in the current international system, the BRICS has the potential to support its members' aspirations to obtain global status. The differences among the BRICS countries in areas including culture, economic size and structure, political systems, and especially values have often led to questions about the logic and future of the group. However, over the past six years the BRICS has succeeding in building institutions such as the New Development Bank (NDB). The structural factor is the overlooked reason behind BRICS institution building, namely that as rising powers its members share similar interests to raise their international status by enhancing their cooperation.

Both Russia and China are permanent members of the UNSC, but they are not fullfledged powers, especially not in the global economic governance system. The other BRICS members do not have prominent international platforms where they can demonstrate their international ambitions. Alhough India, Brazil and South Africa are frequently elected to the UNSC, the BRICS is an increasingly important multilateral platform for these rising powers to practise their international role. Against this backdrop, all BRICS members value the high global profile of the group to demonstrate their approach to global issues and safeguard their broadened overseas interests. To date, the common theme of BRICS summits is to promote the reform of the current system of global economic governance, which makes it clear that the members' objective is to build their influence at the global level rather than at the regional level. A global agenda could help them both raise their international profile and overcome the differences among them. Even the engagement process with regional African and South American leaders begun by the BRICS was mainly to raise their voices in shaping the post-2015 development agenda.

Second, although all BRICS members have interests in Asia, it is hard to build a strong common approach. This is partially due to members' weak capacity and strong concept of state sovereignty. Brazil's economic ties with Asia has grown rapidly in the past decade. China has been Brazil's largest trading partner since 2009. The establishment of the Pacific Alliance is a clear indication that the whole Latin American region is increasingly treating Asia as an important economic partner. Against the backdrop of the Ukraine crisis, Russia is trying to engage 
with more Asian countries beyond China. India's Prime Minister Narendra Modi is turning the "Look East Policy" into the "Act East Policy" [PTI, 2014]. China has also been adjusting its periphery policy against the background of the rebalancing strategy of the U.S. administration under Barack Obama. To build strong ties with the region, a stable and prosperous Asia is in the interests of all BRICS countries.

Indeed, all BRICS members value Asia's stability and prosperity, but that does not mean that they have set this as a priority, or have the capacity to achieve that goal. Even the latest academic analysis of China's approach to the BRICS does not show that it was using the group to shape Asia's order [Cheng, 2014]. The post-World War II security order in Asia has been dominated firmly by the so-called "hub and spoke" system, namely the system of U.S. bilateral allies. The international order in East Asia is described as one of regional security ties to the United States and economic ties to China [Ikenberry, 2004]. That means that neither China nor India has had enough influence on Asia's security affairs. The rise of China and India might not only be attractive in economic terms but might also bring some new security arrangements to the region. At the Conference on Interaction and Confidence-Building Measures in Asia (CICA) in $2014 \mathrm{Xi}$ Jinping argued that Asian affairs should be solved by Asians, suggesting that the CICA should be a platform for dialogue on Asian-wide security issues, and that a new framework on regional security cooperation should be built on the CICA. Such a CICA-based regional security framework would be considerably different from a U.S.-dominated hub-andspoke security framework.

However, given the difficult relationships among China, Korea and Japan and their differing attitudes regarding historical issues, the powerful BRICS members of China and India could not establish a strong regional security framework in the short term. Under Lula's presidency Brazil's efforts to solve the Iran nuclear crisis in 2010 failed to get support from the Permanent Five (P5) members of the UNSC. Dilma Rousseff has put most of her energy into economic cooperation and domestic issues rather than into Brazil's foreign policy agenda. Furthermore, neither Brazil nor South Africa have strong influence outside of their own regions. Controversial territorial issues have also made it difficult to build a high level of strategic trust between China and India. Both countries need time to build trust regarding their coexistence in the Indian Ocean over the next decade.

As well as having weak capacity, the BRICS countries attach a strict concept of state sovereignty in dealing with regional issues, which leads them to adopt either strictly national positions or purely defensive positions [Laidi, 2012]. Their lack of capacity, and the fact that they have not prioritized the issue, has meant that a liberal and strong U.S.-led security order in the region remains influential.

Third, an obvious fact is that Asia lacks such regional integration achievements as the regional institutions of South America and Africa, which have prevented a strong Asian agenda from being established by the BRICS. Brazil and South Africa's leadership role within their respective regions is stronger than the role played by India and China in Asia. The Association of Southeast Asian Nations (ASEAN), rather than China or India, plays the leading role in Asian regional integration. There is no trend to develop a peaceful regional system of economic integration and an ambitious agenda for political union such as that of the European Union. Both Brazil and South Africa have their competitors for regional leadership but unlike the Asian situation, a common integration agenda is shared by all the countries in South America, and by all the countries in Africa. The 2015 BRICS summit might include dialogue with leaders from Central Asia, which might be repeated when the next summit is held in India in 2017. However, it is difficult to bring most Asian leaders, or a broad Asian agenda similar to the African agenda, to the BRICS summits. 
Considering the dominance of the U.S. in maintaining regional security, and the diversified economic dynamics of the region, the Asian BRICS members prefer their own multilateral initiatives to shape regional order. China has initiated some ideas such as "One Belt One Road" and the new Asia Infrastructure Investment Bank (AIIB). India is trying to deepen its involvement in broad Asia-Pacific regional cooperation beyond South Asia. There is a possible trend developing of trilateral cooperation among China, Russia and India to deal with Asian affairs. China and India both signed on as founding members of the AIIB in 2014. Russia and China support India's acceptance as a member of the Shanghai Cooperation Organization (SCO), which has been increasingly influential in promoting sub-regional economic and security cooperation. At their meeting in February 2015, the foreign ministers of Russia, India and China [2015] agreed to establish a trilateral consultation mechanism on Asia-Pacific affairs. This new consensus on coordinating Asian affairs among the three Asian members of BRICS might help the group to develop a stronger Asian agenda.

\section{A Possible Asian Agenda for the BRICS}

The BRICS countries have accumulated sizable material wealth, but they still lack enough legitimacy or soft power to achieve great power status. Unilateral behaviour usually decreases an actor's legitimacy while multilateral actions will increase legitimacy in international relations. As an emerging important forum to provide international public goods and promote reform of the international system, the BRICS faces peer competition from established multilateral institutions. There are many sub-regional or trans-regional institutions and institutions led by great powers including the SCO, the ASEAN Regional Forum, the East Asia Summit, the Asia-Pacific Economic Cooperation (APEC) forum, CICA and the Six-Party Talks on North Korean Nuclear Issues. The weakness of the BRICS is that it lacks legitimacy and concrete areas of involvement in dealing with Asian affairs. The NDB will actively finance the regional infrastructure projects of the Asian countries, although this function overlaps with the newly established AIIB. The NDB's Contingency Reserve Arrangement, similar to the Chiang Mai Initiative, will mainly serve BRICS members in the near future. The first challenge for the BRICS in building a strong Asian agenda is to find an suitable area for cooperation.

Although most BRICS members do not have a strong or direct influence on Asian security, it is possible for the BRICS to affect the approaches and solutions to issues and institution building by expressing the group's views. For example, BRICS countries support a peaceful, safe, open and cooperative information space; an inclusive and peaceful Afghanistan run and owned by the Afghan people; a comprehensive and long-term solution to the Iran nuclear issue; a UN-led solution of the conflict between Israel and Palestine; a political solution to Syria's domestic conflict; and a stable and inclusive Iraq. These views are attractive since they were born in the real situations of these countries and are based on a comprehensive security outlook, which is helpful for maintaining the long-term stability and security of Asia. As influential emerging powers in the post-World War II order, the BRICS countries share a common interest in maintaining the authority of the UN Charter, and building an international security order with fairness and justice. To some extent, support from the BRICS in building a new regional security framework for Asia will add legitimacy to the new framework.

There has been some competition regarding the future regional order in Asia. In his 2015 State of the Union Address, Obama [2015] said that although China wants to write the rules for the world's fastest-growing region, the U.S. should write those rules. In fact, neither the United States nor China can write the rules for Asia; those rules will be written by all the stakeholders from the region. Compared with the exclusive and non-transparent Trans-Pacific Partnership 
(TPP) process, the BRICS might be more interested in supporting an open and future-oriented free trade agreement (FTA) and economic cooperation strategy for the Asia-Pacific region. Russia and China have expressed their support for India to play a larger role within APEC even though it is not a member. TPP's door is still closed to all the BRICS members. The BRICS countries all share the concern of being isolated in the next-generation economic order by updated economic cooperation agreements such as the TPP and the Transatlantic Trade and Investment Partnership (TTIP). Against this backdrop, BRICS countries especially hope to keep the Asia-Pacific market open and to be involved in the process of reshaping the regional economic rules. It is not an easy job to do, however, because there is still no FTA within the BRICS and the level of members' internal economic cooperation remains very low. The BRICS needs to improve that internal cooperation before it can lead Asian economic cooperation.

Furthermore, economic cooperation between BRICS countries and Asia also faces the challenge of remaining sustainable. The 2008 financial crisis not only affected the economic growth model of developed countries, but also challenged the economic cooperation model among BRICS countries. Even though their trade relationship includes high-tech goods such as aircraft and satellites, the main model is the exchange of raw materials for manufactured goods. The greatest challenge here is how China can use its high-tech and capital advantage to help the rest of the BRICS members to make economic cooperation more sustainable. None of the other BRICS members are involved in the Asian production chain, which prevents the group from developing a high-level of economic cooperation with Asia. The good news is that the BRICS is aiming to build a closer economic relationship through more sustainable economic partnerships. To deepen their economic ties with Asia, BRICS members need on the one hand to open their domestic markets to Asian capital and goods, and on the other hand to invest more in Asian countries and accelerate the construction of mutual infrastructure. The NDB might be a useful tool for enhancing economic ties by providing more intellectual and capital support. The NDB would do well to prioritize sustainable projects in Asia, in addition to financing infrastructure, to avoid unnecessary competition with AIIB.

The NDB provides an opportunity for these emerging powers, with the exception of Russia, to act as real global players for the first time. China's previous dominant influence was mainly in East Asia area, before the modern system based on state sovereignty. China's Asia strategy needs to be updated to reflect today's regional realities, which include the United States as a strong external power and an equally capable Japan. India is trying to be accepted as a true Asia-wide power. In contrast to the preference of Brazil and South Africa for using regional institutions to solve regional security issues, China and India have preferred bilateral means rather than multilateral ones. In recent history Brazilian and South African influence has also been limited in their regions. Domestic debates about their global role, especially in Asia, are now emerging without a mature international relations theory to support it. Brazil's concern about Latin America's turning to Asia and the TPP relates mostly the possible weakening of South American integration [Abdenur, 2015]. Against this historical background and in the current situation, it is necessary to foster more societal connection at the level of intellectuals, students and think tanks to build up a solid and suitable Asian policy for the BRICS. The BRICS Think Tank Council should develop a theme based on the group's Asian agenda.

Such an Asian agenda would not be an anti-U.S. strategy. The BRICS countries still value the role of the United States in maintaining the region's stability and prosperity. However, as rising powers and new engines of economic growth for Asia, BRICS countries might encourage more independent regionalism or offer more options for solving regional issues. As rising powers, the Asian members of BRICS hope to play a larger role. Xi made separate special visits to Korea and Mongolia. Modi set its neighbouring countries and Japan as diplomatic priorities. 
Russia's recent engagement with North Korea showed its geopolitical ambitions in Asia. At the trilateral foreign ministers meeting in 2015, China, India and Russia endorsed their support of an open, inclusive, indivisible and transparent security and cooperation architecture in Asia [Foreign Ministers of Russia, India and China, 2015].

Another important aspect is the Asia's relevance to the enlargement of BRICS membership. There are more emerging economies in Asia than in other regions. It is highly possible for the BRICS to recruit new members from Asia in the near future. The BRICS members regard their cooperation as South-South cooperation, which might open the group's door only to the region's developing countries. However, the BRICS should open its door wider to include not only Indonesia but also Korea and Mexico, given their role in promoting international development cooperation. A more diversified membership with successful development experiences will increase the attractiveness of the BRICS in Asia and beyond. In the long run, a stronger NDB also needs financial support from dynamic Asian economies.

\section{References}

Abdenur A.E. (2015) Brazil as a rising power: coexistence through universalism. In: C. de Coning, T. Mandrup and L. Odgaard, eds., The BRICS and coexistence: an alternative vision of world order. Abingdon: Routledge, pp. 49-74.

Cheng J.Y.S. (2014) China's approach to BRICS. Journal of Contemporary China 24(92), pp. 357-75. doi: 10.1080/10670564.2014.932518.

Foreign Ministers of Russia, India and China (2015) "Joint Communiqué of the 13th meeting of the foreign ministers of the Russian Federation, the Republic of India and the People's Republic of China." Beijing, 2 February. Available at: http://www.fmprc.gov.cn/mfa_eng/wjdt_665385/2649_665393/t1233638.shtml (accessed 25 May 2015).

Ikenberry G. J. (2004) American hegemony and East Asian order. Australian Journal of International Affairs 58(3), pp. 353-76. Available at: http://www.ou.edu/uschina/SASD/SASD2005/2005readings/Ikenberry $2004 \% 20$ AmHegEA.pdf (accessed 25 May 2015).

Laidi Z. (2012) BRICS: sovereignty power and weakness. International Politics 49(5), pp. 614-32. doi: 10.1057/ ip.2012.17.

O’Neill J. (2001) Building better global economic BRICs. Goldman Sachs Global Economics Paper No. 66. Available at: http://www.goldmansachs.com/our-thinking/archive/archive-pdfs/build-better-brics. pdf (accessed April 2015).

Obama B. (2015) "State of the union address 2015." Washington DC, 20 January. Available at: https://www. whitehouse.gov/the-press-office/2015/01/20/remarks-president-state-union-address-january-20-2015 (accessed 25 May 2015).

PTI (2014) "Look East” policy now turned into "Act East” policy: Modi. The Hindu, 13 November. Available at: $\quad$ http://www.thehindu.com/news/national/look-east-policy-now-turned-into-act-east-policy-modi/ article6595186.ece (accessed 25 May 2015). 